\title{
A Review of Cost Analysis Study of Farm Tractor
}

\author{
Rahul Makkar ${ }^{1 *}$, Badar E Aalam, Mukesh Jain ${ }^{2}$ and Ashwani \\ ${ }^{1}$ Department of Soil and Water Engineering, College of Agricultural Engineering and \\ Technology, CCS Haryana Agricultural University, Hisar - 125004, Haryana, India \\ ${ }^{2}$ Department of Farm Machinery and Power Engineering, College of Agricultural \\ Engineering and Technology, CCS Haryana Agricultural University, \\ Hisar - 125004, Haryana, India \\ *Corresponding author
}

A B S T R A C T

\begin{tabular}{l} 
Ke y w o r d s \\
$\begin{array}{l}\text { Tractor power } \\
\text { rapid growth of } \\
\text { farm production }\end{array}$ \\
\hline Article Info \\
$\begin{array}{l}\text { Accepted: } \\
\text { 22 February } 2020 \\
\text { Available Online: } \\
\text { 10 March } 2020\end{array}$ \\
\hline
\end{tabular}

Today, tractor is one of the most important power sources in agriculture. Effect of tractor power on agriculture is considerable. The use of modern technology during latter decades resulted in rapid growth of farm production. Tractors and farm machinery are important samples of this modern technology. The quality of inputs of mechanization and consequently land and labor productivity in both situations, may differ considerably. The study was planned and conducted during year 201516.The tractors were selected from the directorate of farm CCSHAU, Hisar, Central state farm, hisar and proximity area farmers. In our survey we calculate the actual value of the fuel consumption of tractor from the log book of directorate farm CCSHAU, Central state farm hisar, various farmers and dealers of various tractor agencies. Insurance is taken 1.5-2\% from tractor operator farmers and dealers. After interacting with farmers there are 3-4 services are required for proper working of farm tractor.

\section{Introduction}

Today, tractor is one of the most important power sources in agriculture. Effect of tractor power on agriculture is considerable. The use of modern technology during latter decades resulted in rapid growth of farm production. Tractors and farm machinery are important samples of this modern technology. The quality of inputs of mechanization and consequently land and labor productivity in both situations, may differ considerably. Costs of owning and operating of farm machinery represent 35 to $50 \%$ of the costs of agricultural production when excluding the land. The repair and 
maintenance cost ( $\mathrm{R}$ and $\mathrm{M})$ is an important item in costs of owning and operation. In general, the costs other than those for repair and maintenance cost usually decrease with increasing usage, but the reverse is true with respect to repair and maintenance costs. The cost of repair and maintenance is usually about $10 \%$ of the total cost; as the machine age increases the cost increases until it becomes the largest cost item of owning and operating of farm machines.

Agricultural engineers have done many studies regarding repair and maintenance of farm tractor. Several studies were conducted in both developed and undeveloped countries either to develop models to determine the cost during a certain period or to get absolute numbers to represent owning and operating certain tractors.

One of the most important items influencing the profitability of farming operations is the cost of owning and operating the farm machines. Accurate cost estimates play an important role in every machinery management decision, namely, when to trade, which size to buy, how much to buy, etc.

\section{Details of various methods for cost analysis of tractor}

Farm machinery costs can be divided into two categories: fixed cost, which occur regardless of machine use and operating costs, which vary directly with the amount of machine use.

\section{Fixed costs}

These costs depend on how long a machine is owned rather than how much it is used. Fixed cost includes depreciation, interest, taxes, shelter and insurance.

\section{Operating costs}

It is also called as the variable costs. It varies in proportion to the amount of machine used. The operating cost consists of repair and maintenance costs, fuel costs, oil or lubrication costs and labour costs.

\section{Fixed costs}

\section{Depreciation}

Depreciation means a loss in the value of a machine due to time and use. Often, it is the largest of all costs. Machine depreciate, or have a loss of value, for several reasons, such as, age of machine, wear and tear of machine and obsolescence. There are several different methods to calculate the depreciation. These include the following:

\section{Straight-line method}

In the straight-line depreciation method, an equal reduction of value is used for each year the machine is owned. This method can always be used to estimate costs on a specific period of time, provided the proper salvage value is used for the age of the machine. The annual depreciation value can be calculated from the following expression:-

$$
\mathrm{D}=\frac{\mathrm{P}-\mathrm{S}}{\mathrm{L} \mathrm{H}}
$$

Where,

D = average annual depreciation, Rs/h

$\mathrm{P} \quad=$ purchase price, Rs.

$\mathrm{S} \quad=$ salvage value, taken as $10 \%$ the purchase price

$\mathrm{L} \quad=$ life of machine, years

$\mathrm{H} \quad=$ annual use of machine, hours 


\section{Declining-balance depreciation method}

It reflects the actual value of a machine at any age rather than the value found from the straight-line method or sum of the digits method. With the declining balance method, a machine depreciates a different amount for each year, but the annual percentage of depreciation is the same.

\section{Sum-of-the years digits method}

It is a much more accurate method of estimating the true value of a machine at any age because the annual depreciation rate decreases as the machine gets older.

\section{Interest on investment}

A large expensive item after depreciation for agricultural machinery is the interest. It is a direct expense item on borrowed capital. Even if cash is paid for purchased machinery, money is tied up that might be available for use elsewhere in the business. Interest rates vary considerably but usually are between 12 and 16 percent. Annual interest is calculated on an average investment by using the prevailing interest rate by the following formula:

$$
I=\frac{P+S}{2} x \frac{i}{-100}
$$

Where,

I = annual interest charge, Rs./year

$\mathrm{P}=$ purchase price, Rs.

$\mathrm{S}=$ salvage value, $\mathrm{Rs}$.

$\mathrm{i}=$ interest rate, per cent

\section{Insurance, housing and tax}

Insurance and shelter charges together are taken @ 3\% of the purchase price per year

\section{Variable costs}

Variable cost includes, repair and maintenance costs, fuel costs, lubrication (oil) costs and labour costs.

\section{Repair and maintenance costs}

Repair and maintenance costs are considered as an essential and significant part of machinery ownership. Occasional repairs and periodic maintenance are required to maintain a machine in good working order and ensure a high degree of reliability. The more a machine is used, the greater is its need for repair. Repair costs consists of the expenditures incurred for the spare parts and the labour for repairs made in a shop or on the farm. Repair costs vary from one geographical region to another because of the differences in machinery use, labour wages and prices of spares. Repair costs increases with the age of a machine but tend to level off as a machine becomes older. The accumulated repair and maintenance costs

\section{Fuel cost}

With tractors and other powered farm equipment, the cost of fuel must be included in the total machine charge .It is calculated on the daily usage of fuel in various operations

\section{Lubrication oil}

Lubrication oil is calculated to estimate how much lubrication oil is used for proper working of tractor. It is $30 \%$ of total fuel used in tractor.

\section{Labour charges}

The cost of operator and labour is calculated from the actual operator and labour charges paid in Rupees per day at the prevailing rates in that region. 
The actual cost of the tractors which are considered in this project are taken from the various dealers of the different tractors in hisar district.

Table.1 Cost of various tractors

\begin{tabular}{|l|c|}
\hline Tractor & Estimated Cost (in lakhs) \\
\hline MF1035 & 5 \\
\hline HMT6522 & 7.80 \\
\hline ARJUN NOVO 605 DI & 7.50 \\
\hline FORD 7500 & 6.50 \\
\hline JOHN DEERE 5055 E & 7.60 \\
\hline
\end{tabular}

\section{Fixed cost}

It includes depreciation, interest and housing, tax and insurance.

\section{Depreciation}

\section{Straight line method}

The calculated data of various tractors that is estimated by the straight line method is as following.

Table.2 Depreciation by straight line method

\begin{tabular}{|l|c|}
\hline Tractor & Depreciation(Rs/hr) \\
\hline MF1035 & 45 \\
\hline HMT6522 & 70.2 \\
\hline ARJUN NOVO 605 DI & 67.5 \\
\hline FORD 7500 & 58.5 \\
\hline JOHN DEERE 5055E & 68.4 \\
\hline
\end{tabular}

\section{Declining balanace method}

With the declining balance method, a machine depreciates a different amount for each year, but the annual percentage of depreciation is the same. The following data is calculated by declining balance method of various tractors. 
Table.3 Depreciation by declining balance method

\begin{tabular}{|l|l|l|l|l|l|}
\hline $\begin{array}{l}\text { Value } \\
\text { remained } \\
\begin{array}{l}\text { Year } \\
\text { wise }\end{array}\end{array}$ & $\begin{array}{l}\text { MF1035 } \\
(\mathbf{R s )}\end{array}$ & $\begin{array}{l}\text { HMT6522 } \\
\text { (Rs) }\end{array}$ & $\begin{array}{l}\text { ARJUN } \\
\text { NOVO } \\
\mathbf{6 0 5} \\
\text { (Rs) }\end{array}$ & $\begin{array}{l}\text { FORD } \\
\mathbf{7 5 0 0} \\
(\mathbf{R s )}\end{array}$ & $\begin{array}{l}\text { JOHN } \\
\text { DEERE } \\
\mathbf{5 0 5 5} \text { E } \\
\text { (Rs) }\end{array}$ \\
\hline $\mathbf{1}$ & 400000 & 624000 & 600000 & 520000 & 608000 \\
\hline $\mathbf{2}$ & 320000 & 499200 & 480000 & 416000 & 486400 \\
\hline $\mathbf{3}$ & 256000 & 399360 & 384000 & 332800 & 389120 \\
\hline $\mathbf{4}$ & 204800 & 319488 & 307200 & 266240 & 311296 \\
\hline $\mathbf{5}$ & 163840 & 255590 & 245760 & 212992 & 249036 \\
\hline $\mathbf{6}$ & 131072 & 204472 & 196608 & 170393 & 199229 \\
\hline $\mathbf{7}$ & 104857 & 163577 & 157286 & 136314 & 159383 \\
\hline $\mathbf{8}$ & 83886 & 130862 & 125829 & 109051 & 127506 \\
\hline $\mathbf{9}$ & 67108 & 104689 & 100663 & 87241 & 100663 \\
\hline $\mathbf{1 0}$ & 53687 & 83751 & 80530 & 69793 & 81604 \\
\hline
\end{tabular}

Table.4 Depreciation by sum of the year digit method

\begin{tabular}{|l|l|l|l|l|l|}
\hline $\begin{array}{l}\text { Depreciation } \\
\text { year wise }\end{array}$ & $\begin{array}{l}\text { MF1035 } \\
\text { (Rs/year) }\end{array}$ & $\begin{array}{l}\text { HMT6522 } \\
\text { (Rs/year) }\end{array}$ & $\begin{array}{l}\text { ARJUN } \\
\text { NOVO 605 } \\
\text { (Rs/year) }\end{array}$ & $\begin{array}{l}\text { FORD 7500 } \\
\text { (Rs/year) }\end{array}$ & $\begin{array}{l}\text { JOHN DEERE } \\
\text { 5055 E } \\
\text { (Rs/year) }\end{array}$ \\
\hline $\mathbf{1}$ & 81818 & 127636 & 122727 & 106363 & 124363 \\
\hline $\mathbf{2}$ & 73636 & 114872 & 110454 & 95727 & 111927 \\
\hline $\mathbf{3}$ & 65454 & 102109 & 98181 & 85090 & 99490 \\
\hline $\mathbf{4}$ & 57272 & 89345 & 85909 & 74454 & 87052 \\
\hline $\mathbf{5}$ & 49090 & 76581 & 73636 & 63818 & 74618 \\
\hline $\mathbf{6}$ & 40909 & 63818 & 61363 & 53181 & 62181 \\
\hline $\mathbf{7}$ & 32727 & 51054 & 49090 & 42545 & 49745 \\
\hline $\mathbf{8}$ & 24545 & 38290 & 36818 & 31909 & 37309 \\
\hline $\mathbf{9}$ & 16363 & 25527 & 24545 & 21272 & 24872 \\
\hline $\mathbf{1 0}$ & 8181 & 12763 & 12272 & 10636 & 12436 \\
\hline
\end{tabular}

\section{Sum of the year digit method}

It is a much more accurate method of estimating the true value of a machine at any age because the annual depreciation rate decreases as the machine gets older

\section{Interest}

A large expensive item after depreciation for agricultural machinery is the interest. It is a direct expense item on borrowed capital. Interest rates vary considerably but usually are between 10 percent. The calculate data for the interest is described in below table. 
Table.5 Calculation of interest

\begin{tabular}{|l|c|}
\hline TRACTOR & Interest(Rs/hr) \\
\hline MF1035 & 27.50 \\
\hline HMT6522 & 42.90 \\
\hline ARJUN NOVO 605 DI & 41.25 \\
\hline FORD 7500 & 35.75 \\
\hline JOHN DEERE 5055 E & 41.80 \\
\hline
\end{tabular}

Insurance, housing and tax

Insurance and shelter charges together are taken@3\% of the purchase price per year. The calculated data of insurance, housing and taxes is as follows.

Table.6 Calculation of insurance, tax and housing

\begin{tabular}{|l|c|}
\hline TRACTOR & ESTIMATED VALUE(Rs/hr) \\
\hline MF1035 & 15 \\
\hline HMT6522 & 23.5 \\
\hline ARJUN NOVO 605 DI & 22.5 \\
\hline FORD 7500 & 19.5 \\
\hline JOHN DEERE 5055 E & 22.8 \\
\hline
\end{tabular}

\section{Variable costs}

It includes fuel costs, oil or lubrication costs, labour costs and repair and maintenance costs.

Fuel cost
The consumption of fuel is collected from the Log book of tractors from Director of farm, CCSHAU and Central state farm, Hisar .From that data per hour consumption of fuel is tabulated below.

Table.7 Calculation of fuel cost

\begin{tabular}{|l|l|}
\hline TRACTOR & Fuel cost $($ Rs/hr) \\
\hline MF1035 & 166 \\
\hline HMT6522 & 189 \\
\hline ARJUN NOVO 605 DI & 180 \\
\hline FORD 7500 & 193 \\
\hline JOHN DEERE 5055 E & 157.5 \\
\hline
\end{tabular}




\section{Lubrication cost}

The consumption of lubrication is taken
$30 \%$ of the fuel cost which is given below in table.

Table.7 Calculation of lubrication cost

\begin{tabular}{|l|l|}
\hline TRACTOR & Lubrication cost $(\mathbf{R s} / \mathbf{h r})$ \\
\hline MF1035 & 49.8 \\
\hline HMT6522 & 56.27 \\
\hline ARJUN NOVO 605 DI & 54 \\
\hline FORD 7500 & 58.7 \\
\hline JOHN DEERE 5055 E & 47.25 \\
\hline
\end{tabular}

Repair and maintenance cost

The cost of repair and maintenance is taken
$6 \%$ of the total cost price of the tractor. The calculated value of repair and maintenance is given below in table.

Table.8 Repair and maintenance cost

\begin{tabular}{|l|c|}
\hline TRACTOR & Repair and maintenance cost $(\mathbf{R s} / \mathbf{h r})$ \\
\hline MF1035 & 30 \\
\hline HMT6522 & 46.8 \\
\hline ARJUN NOVO 605 DI & 45 \\
\hline FORD 7500 & 39 \\
\hline JOHN DEERE 5055 E & 45.6 \\
\hline
\end{tabular}

\section{Labour cost}

Labour cost of one labour is taken as Rs $50 / \mathrm{hr}$.

From the survey of depreciation cost at the end of the year is near about 60000-750000 but from the existing methods, the depreciation cost is different. The repair and maintenance cost is taken $6 \%$ of the total cost of the tractor but from the survey it is observed that repair and maintenance is lower from the $6 \%$ and different for the different hp ranges.

Housing is taken $1 \%$ of the tractor cost in existing formulaes but in actual it is 4000050000 for a tractor. Insurance taken in the existing formulaes of cost analysis is taken $1 \%$ of the tractor cost but in actual it is 1.5 $2 \%$. Working hours of tractor per year taken in existing formulaes are 1000 but in actual conditions the working hours are 700-800.

The average life of tractors taken in the existing formulaes is 10 year but in actual life of tractors is $12-15$ years. Salvage value taken in the cost analysis methos is $10 \%$ of the price of tractor but in actual is $25-30 \%$ of tractor cost.

\section{References}

Adekoya, LO. and Otono, PA. 1990. Repair and maintenance costs of agricultural tractors in Nigeria. Tropical 
Agriculture, 67(2): 119-122

African journal of agricultural research, June 2014.

American journal of agricultural economic Volume 65 no.2, May 1983

Anderson, AW. 1988. Factors affecting machinery costs in grain production.

Central state Farm, Hisar.

Department of Agricultural and Consumer Economics College of Agricultural, Consumer and Environmental Sciences University of Illinois at UrbanaChampaign.

Devrajani, B.T.; Ansari, A.Q. and Butler, J.L.1979. Operation of Agricultural machinery in developing countries. Agricultural Mechanisation in Asia. 10(3):n. ASAE Paper No.88-1057

Directorate of Farm, CCSHAU Hisar

Farrow, S., J.F. Shepherd and H. Waelti, 1980. A regional test of machinery repair cost equations. ASAE Paper No. 80-1017.

Rotz, C.A. and W. Bowers, 1991. Repair and maintenance cost data for agricultural equipment. ASAE Paper No. 91-153.

Rotz, C.A., 1987. A standard model for repair costs of agricultural machinery. Applied Engineering in Agric., 3(1): 3-9.

\section{How to cite this article:}

Rahul Makkar, Badar E Aalam, Mukesh Jain and Ashwani. 2020. A Review of Cost Analysis Study of Farm Tractor. Int.J.Curr.Microbiol.App.Sci. 9(03): 2914-2921. doi: https://doi.org/10.20546/ijcmas.2020.903.335 